08

\title{
NOTION OF WATER WAR: A LEGEND OR PHENOMENON?
}

\author{
Yunusa Hassan \\ Department of Geography, Umar Suleiman College of Education Gashua, Nigeria \\ Department of Geography, NIMS University, India \\ Email: contactyunusah@gmail.com
}

How to cite this paper:

Hassan, Y. (2021). Notion of Water War: A Legend or Phenomenon? Journal of Global Resources, Vol. 07 (02)

DOI:

10.46587/JGR.2021.v07i02.008

Received: 21 March 2021

Reviewed: 10 April 2021

Revised: 26 April 2021

Final Accepted: 25 May 2021

OPEN $\bigcirc$ ACCESS

Freely available Online www.isdesr.org

\begin{abstract}
Water is precious and believed to the king among all resources. For this reason, sustainable management of water during this millennium must take into accounts water demands as well as the most pressing issues of competing diverse usergroups. This is a review of the popular notion of water war and its present-day perspective. The study is a critical analysis of diverse facts, reports, data and assumptions on the leading causes of water-allied issues, conflicts and disputes in order to establish whether the notion is a myth or a phenomenon. Using data mainly retrieved from secondary sources, this study broadly focuses on developing economies in mostly Africa and Asia, however, a more specific interest is placed on Nigeria as a case study with the aid of complementary primary data collected during the conduct of interview. This study held the view that the axiom is strongly associated to different issues linked to regional developmental and economic status, for instance, regions with developed economies having lesser likelihoods water war because they are mostly deemed to be having stronger financial institutions and purchasing power, higher level of infrastructural development, improved standard of living, stronger and functional institutional policies. Therefore, with recent global unending competition in pursuits for various developmental upgrades and increasing roles of water resources in domestic, agricultural and industrial sectors, this study adequately surmises the modern vantage point of waterallied conflicts and disputes.
\end{abstract}

Keywords: Climate Change, Common Resource Conflict, Natural Resource Management 


\section{Introduction}

Among the most pressing issues of the millennium is the management of the earth finite resource such as water, fossil fuels and other essential mineral compounds. Earlier crude oil was regarded as the black gold, but nowadays, water is the blue gold (Wolf, 1997; Abu-Lohom et a., 2018). Throughout the history of mankind, water was regarded as a fundamental resource that is essential to man's activities. However, the amount of available freshwater resources has severely threatened by both natural as well as anthropogenic processes. These processes include issues such as climatic variations, booming population, cosmopolitan lifestyle, rapid change in land cover land use, among others. With recent expanding roles of water in the 21 st century, the importance of water must not be over emphasized.

Many regions around the world are suffering from diverse issues such as drought, hunger, poverty, and diseases, however, many studies have succinctly linked these issues to be either directly or indirectly linked to water (Gleick, 1993; Dowdeswell and Hania, 2014; Varshney and Hassan, 2019; Schillinger et al., 2020). Therefore, this and the likes mandated the urgent need for efficient management of water resources at all level. As reported in many studies, whenever a locality runs out of water, the inhabitants of the affected territory have to leave their home and migrate to new lands (Hauge and Tanja, 1998; Kartin, 2001; Gleick, 2019). These migrations often cause tension between the newcomers (migrants) and the originallocal population (indigenes) that is why these tensions and conflicts generate more and more refugees and migrants who have to wander further (Gleick, 2019). This is one of the reasons why significant numbers of people leave the African continent every year and migrates to Europe and other parts of the world seeking for better life (Gray and Bilsborrow, 2013; Gowan, 2017). That is why the European Union is looking for solutions to the migration problem; however, the outcome of any possible solutions could cause more conflicts in Africa, which could generate more migrants and asylum seekers.

In view of the above summations, the present review critically examines substantial number of cases of water-allied conflicts and disputes in various part of the world in order to either confirm or refute the water war axiom and accordingly establish whether the notion is a 'myth' or a 'phenomenon'. Moreover, the study also broadly focuses on developing economies of Africa as a continent and specifically focuses on Nigeria as a case study at country level.

\section{Theoretical Framework}

In milieu of this study, water war is regarded as subject of water-allied crisis, conflicts and disputes that resulted to fatality of about 25 persons and above within a geographic area (Turton, 2000; Murray, 2007). Water war in the context of resource scarcity, sustainability and degradation within the overarching phenomenon of climate change and other related manmade factors has been addressed by several theoretical formulations (Davis, 1959; Hardin, 1968; Oberschall, 1978; Smith, 1999; Murray, 2007). Therefore, in line with these studies, the present study employed the theory of "tragedy of the commons". The theory of tragedy of the commons states that when a resource is collectively owned by a group of people, each will exploit the resource, and possibly overused it, yet ignoring the group's collective interest, and thus ultimately destroy the resource (Hardin, 1968; Turton, 2000).

The theory of tragedy of commons as postulated by Hardin (1968) further explained the tragedy by using the example of a pasture which is open to all to user-groups. This open pasture is used by herdsmen to allow their cattle to graze and each herder will continue to add cattle to the pasture so as to expand the amount of proceeds coming from their respective herds. However, the commons dilemma stands as a model for a great variety of present resource problems such as freshwater scarcity, crisis and pollution(Hardin, 1968). So, this 
study in terms of Hardin's theory is represented in the following context; the earth's water resource is the common whereas the tragedy is the conflicts and disputes resulting from waterallied demand, access, management, utilization and scarcity among the diverse user-groups. As water resource become scarcer, competition for access will often results to disputes and conflicts over them, hence, these may consequently result to loss of lives and properties.

In order to succinctly frame the study's problem, the present study adopted the approach of relative deprivation theory that which has been proved to be highly useful in the analysis of violence, rebellion, and social movement at either individual or group level. This theory usually provides a theoretical loop where the most vulnerable individual or group of individuals express grieved based actions against their respective competing user-groups (Davis, 1959). In this theory, individual or group of individuals usually protest or rebel against their condition that is mainly associated with environmental stress (Davis, 1959).In understanding the relative deprivation theory as a framework for water-conflict nexus, this study situates the circumstances of water demands, access, shortages or struggles between competing user-groups where one group seek to out-gain the other largely due to either obvious or potent water shortages and scarcity.

Several studies have proven that resource scarcities can consequently results to environmental depreciation and contradictory action among the resource diverse user-groups (Percival and Homer-Dixon, 1998; Smith, 1999; Baechler, 1999). In line with the study by Percival and Homer-Dixon (1998), this study utilizes this theory to frame the following presumptions about water resources scarcity; supply-induced water scarcity, demand-induced water scarcity as well as structural induced water scarcity. The supply-induced water scarcity is the types of water shortages that are associated to climatic variability and the depletion in the amount of either surface or groundwater resource within an environment, whereas the demand-induced water scarcity mainly arises due to population pressure (growth) in a given environment or an increase in per capita consumption of water that can consequentially triggered an increase in water demand. Lastly, the structural-induced water scarcity is the type of scarcities resulting from inequality in social distribution of water resource; for instance, the organization limit some people access to water to relatively few people or interest group, consequently, this tends to upshots the water demands to capture diverse ecological marginalization.

\section{Global Freshwater Scarcity}

Freshwater scarcity is a puzzling phenomenon when put side by side with the fact that the total surface of the earth itself is two thirds water; the world is composed of over 70 percent water but only less than 3 percent to fully believed to be clean and drinkable freshwater whereas the greater proportion of that freshwater is locked in glaciers and permanent snow leaving human activities with only 1.2 percent that readily available in the surface of the earth ( groundwater 30 percent, and surface and other sources frozen in ice, lakes, river, atmosphere, swamps and soil moisture) (WHO, 2020). Therefore, this has left only as little as less than one percent for both nature and humans to meet their respective domestic, socioeconomic and ecological needs. However, this less than one percent of the global freshwater resource is also believed to be stored in underground aquifers have manifested as rainfall; some reside in natural lakes, man-made storage, and rivers (Wolt, 2011; WHO, 2020). It is believed that climate change and variabilities are capable disrupting man's orderliness, and would continue to disrupt the earth's hydrological cycle through changing the distribution of available freshwater resource. 
Though there are different types of water scarcity must be acknowledged; the most common is the scarcity that occurs when there is a lack of the minimum supply of freshwater resource that are capable of supporting human health, sustaining the world food productions as well as fundamental ecological well-being (Evans, 2010). However, two basic types of water scarcity are identified; the physical and economic scarcity is central to this study. The physical water scarcity occurs when there is a physical lack of water whereas the economic water scarcity describes a situation in which resources are abundant but where insufficient infrastructure and financial capacity prevent people from accessing the water they need (Kartin, 2001; Norland, 2016).

The World Health Organization's fact file on water scarcity substantiates this by reporting that there are parts of the world which have adequate amounts of rainfall and general freshwater and yet scarcity persists (WHO, 2009). Besides economic scarcity, the World Health Organization further added that geographic or physical water scarcity found in areas where there is no access to any freshwater sources (either clean or otherwise) affects onefifth of the about 1.2 billion people of the global population (WHO, 2009). Whether natural or manmade, there are many contemporary conditions that cause freshwater scarcity; therefore, the following are the most common examples:

[i] Growth in world population: The world's population is growing at a very rapid rate and will lead to a growth in the demand for food. This would constitute the single most important cause of pressure on water resources. Over the last generation, most of the increment in food supply has been obtained by an expansion in irrigated farming. Duda et al., (2012) of the Global Environment Facility (GEF) have reported that irrigation and food production is reported to have already used almost 80 percent of total freshwater resources.

[ii] Contamination and pollution. Pollution causes scarcity of normal water supplies as it destroys part of the water resource. This may happen to surface supplies or groundwater, and the pollution may be from industrial effluent, agro-chemical run-off from fields, the casual disposal of human waste, or the release of insufficiently treated sewage from municipal works (Morrison et al., 2009).

[iii] Climatic change and variability: Climatic change reduces the amount of rain that falls and creates new deserts (Soto, 2009). This affects both rain-fed and irrigated agriculture. Crop damage and crop disease are all driven by rainfall and associated humidity (Falkenmark et al., 2007; Ludi, 2009).

\section{Contemporary Water-allied Issues}

The most common water-allied issues lately are the fast diminishing of the earth finite freshwater, freshwater availability, demands, and withdrawals. The freshwater-availability indicator focuses on the per capita availability of renewable freshwater including water from rivers in international river basins (Falkenmark,1989). This study adopted the Falkenmark (1989) concept that take all uses of water into account and designates nations with 1700 cubic meters per person per year of available water as having infrequent water shortages, 1000 cubic meters of water per person per year as being relatively water-stressed nation with about 500 cubic meters or less per person per year or under as indicating a chronic water scarcity. Even though the relative-water-stress indicator mainly focuses on freshwater withdrawals, however, farming accounts for about 70 percent of the usage of the world water and relatively arid agricultural nations may require more water for irrigation than nations with plentiful rainfall or those importing a large share of their food (UN, 2008). Moreover, it is the ratio of annual water withdrawals to the annual freshwater availability. 
High water stress is considered to be a ratio of more than 40 percent; medium-high stress, from 30 to 40 percent; and medium stress, from 20 to 30 percent (UN, 2008). However, these limits are arbitrary and accordingly are considered a nation of high water-stress, even though its current ratio seems sustainable for the indefinite future. The relative-water-stress measure requires a projection of water withdrawals in the future, a calculation that is not easy to make. For example, such calculation was used to predict the aggregate basis water withdrawals which were anticipated to increase to about 32 percent between 2000 and 2025 (Raskin, et al., 1997; UN, 2008).

Table 01: Projected Countries to be Water Stressed in 2025

\begin{tabular}{|l|l|l|}
\hline \multicolumn{1}{|c|}{ Region } & \multicolumn{1}{c|}{ Countries } \\
\hline 1 & Sub-Saharan Africa & $\begin{array}{l}\text { Burkina Faso, Burundi, Cape Verde, Comoros, Djibouti, } \\
\text { Eritrea, Ethiopia, Kenya, Malawi, Rwanda, Somalia, South } \\
\text { Africa, Swaziland, and Sudan }\end{array}$ \\
\hline 2 & $\begin{array}{l}\text { North Africa and } \\
\text { Near East }\end{array}$ & $\begin{array}{l}\text { Afghanistan, Algeria, Bahrain, Egypt, Iran, Iraq, Israel, Jordan, } \\
\text { Kuwait, Lebanon, Libya, Mauritania, Morocco, Oman, Qatar, } \\
\text { Saudi Arabia, Syria, Tunisia, U.A.E., Western Sahara, and } \\
\text { Yemen }\end{array}$ \\
\hline 3 & $\begin{array}{l}\text { Rest of Asia (except } \\
\text { former USSR) }\end{array}$ & $\begin{array}{l}\text { Maldives, India, Korea (South), Pakistan, and Singapore } \\
\text { USSR }\end{array}$ \\
\hline 5 & $\begin{array}{l}\text { North and South } \\
\text { America, and } \\
\text { Oceania }\end{array}$ & $\begin{array}{l}\text { Armenia, Azerbaijan, Belgium, Cyprus, Lithuania, Kazakhstan, } \\
\text { Malta, Moldova, Portugal, Spain, Turkmenistan, Ukraine, and } \\
\text { Uzbekistan }\end{array}$ \\
\hline
\end{tabular}

Source: Raskin, et al. (1997)

In case of global arable land, between 1975 and 2000 there is marked deceleration of the increase in arable land use is also apparent, that is why the total arable land in use only increased by about 6 percent (FAO Stat, 2005). The percentage of global arable land in use that is irrigated in 1961 is about 11 percent, this only increased to 14 percent in 2000 (FAO Stat, 2005). Even though, the total global area under irrigation increased to 46 percent between 1975 and 2000, however, the annual increase was decelerating per capita basis. But during the late $20^{\text {th }}$ century, the need for increase in food production was about 6 percent, however, it was reported lately that to eliminate malnourishment by 2025 and to meet the rising food demand from a greater population and higher incomes, the world food production between 2000 and 2025 must increase by about 41 percent (FAO Stat, 2005).

\section{Water as a Source of Livelihood and Conflicts in Africa}

Throughout the existence of man, water resource remained the most essential resource on the face of earth (Myers, 2002; Wenzlau, 2010). Therefore, any attempt to seize water resource or deprived certain part of the population would consequently results to conflict at either individual or communal level. Africa as the second most arid continent in the world is believed to be defragmented by diverse cultural, religious, economical as well as political divisions (Ngigi, 2009; Abdeen, 2010). It was reported that as division within Africa become more obvious, tensions often rise, especially in terms of water demands and access(Ashton, 2000; Nyong and Fiki, 2005; Abbass, 2012). However, these primary sectors predominantly demand staggering amount of water to operate effectively; however, various studies reported decrease in the amount of annual average precipitation in Africa. Consequently, these decreases in precipitation have resulted to growing migration for greener pasture which in return creates fear of marginalization by the receiving communities (Abbass, 2012; UN, 2017). 
In both the recent past and contemporary world, there are reasonable amount of literature that linked water shortages and scarcities to diverse conflicts and disputes in some part of African as a continent which its significant portion is covered with aridity. For example, in the Northeast African region, several studies reported that the regions around the Nile, Egypt, Sudan, Rwanda and Ethiopia are believed to be the hotspot of water-allied conflicts (Baechler, 1999; Abbass, 2011; Besenyő and Miletics, 2014; Schillinger et al., 2020). Another African region threatened by water-allied conflicts and disputes are the area of Volta River and Senegal River; between Ghana and Burkina Faso, and between Senegal and Mauritania respectively (Gleick, 1993; Kratli, 2008; Adano et al., 2012). There is also an increasing tension in the Westcentral Africa's region around the Lake Chad general area between Chad, Nigeria, Niger, and Cameroun which was largely associated to the decreasing sources of livelihood of the population that depends on that water for livelihood (Varshney and Hassan, 2019). In Southern region of Africa, there are reported patches of disputes and conflicts around the Okavango River involving countries like Lesotho and South Africa republic as well as Botswana, Namibia, and Angola respectively (Pallett, 1997; Black et al., 2008; Treszkai, 2016).

Pressing issues in Africa that are associated with water-allied conflicts and disputes are rapidly increasing throughout the continent as reported by many studies (Kratli, 2008; Abbass, 2011; Adano et al., 2012; Besenyő and Miletics, 2014; Schillinger et al., 2020). According to United Nations estimates in 2017, the total population of Africa as a continent is about 1.2 billion; this means that this continent population alone has constituted about 16 percent of the total world population (UN, 2017).Yet, the continent population is growing at an alarming rate of about 42 million people annually and was project to be about 4.2 billion by 2050 (UN, 2017). Therefore, as the population grow, the water demand for this population will consequently skyrocket. Another factor associated with the Africa's water-allied conflicts and disputes is the recent climatic changes that are further dissected into many factors such as water shortage, drying of surface water resources, drought and desertification (Buseth, 2009; Mearns and Norton, 2010).

Low rainfall and drought are among the most common devastating phenomena in most of the countries in the horn of Africa; for instance, Somalia, Ethiopia, Kenya, and Eritrea (Mearns and Norton, 2010; Adano et al., 2012). Many studies affirmed that is why issues such as famine and drought in countries like Somalia and sub-Saharan countries are reported to be catalysts to the region 'increasing instability, conflicts and disputes (Konczacki, 1978; Shiklomanov and John, 2003; Kis-Álmos et al., 2010). Moreover, another example is the conflict between the pastoral tribes on the border of Kenya and Ethiopia stemming from the struggle for survival during drought (Kartin, 2001; Renzetti, 2002; Gleick, 2006).It is a fact that global instabilities, poor governance, poverty, and different transnational organized crimes executed by various radical and separatist groups are benefitting from the situation (Renzetti, 2002; Gowan, 2017).

Since there is no single indicator that give a complete picture of water stress, therefore, it is accurate to say that most measures adopted by many studies are countrywide and do not indicate the particular areas of a country are experiencing difficulties in, therefore, Nigeria was selected as a case study. According to United Nation (2017), there are about 19 million migrants moving within Africa; with about 9 million of them leaving the continent from countries such as Nigeria, Sudan (Dafur), South-Sudan, and Somalia the forefront. Beyond the contemporary issues of natural resources, there are also other factors that are important such as agriculture, finance, industry, and infrastructure, that is why the geographical location of Nigeria as a country is a relevant aspect (Qoubo, 2012; Groninger et al., 2015). 
In Nigeria, especially across the Northern part of the country where greater percentage of the region' population depend largely on rain-fed agricultural activities (Abbass, 2011). Northern Nigeria is a vast land that is largely covered by savannah and patches of forested areas, and also less densely populated relative to the southern part of the country (Varshney and Hassan, 2019). The northern Nigeria is constituted of 18 states (out of the 36 states of the Nigerian Federation) with a plurality of cultures. According to Abbas (2011), this phenomenon creates potential areas of conflicts with every group projecting its interests in resource allocation, access, management, and control in Nigeria (Konczacki, 1978; Koubi et al., 2014).

Agriculture as the powerhouse of the northern Nigeria's economy was threatened with variabilities in weather pattern seasonally with annual rainfall duration of about 3-5 months with a prolonged dry season (WMO, 1997; Gleditsch et al., 2002; Downing and Patwardhan, 2003; Gartzke, 2011).There are evidences that several studies have supported the preposition that freshwater scarcity breeds conflict (Jacobs, 1980; Obioha, 2005; Oyetade, 2007; Amobi and Onyisi, 2015). According to Konczacki (1978) and Jacobs (1980) posited that freshwater scarcity and insufficient rainfall are causes of social and economic ruins, conditions that leave the pastoralists at the mercy of the sedentary society of predominantly farmers. Studies by Catterson (1990) and Ide (2015) also reported that the same that resource scarcity makes rain-fed farmers to expand their farms into cultivable pastoral land, which in turn brings about displacement of pastoralists, and this consequently push both user-group to resorts to competition for access of the limited available land.

Furthermore, studies by Murray (2007) and Oyetade (2007) have reported that an untold hardship has consistently led to an increasing forced to migrate off land that has become barren. Moreover, another study by Raleigh and Urdal (2009) reported that thousands of farmers and their families become migrants and have been opined that freshwater scarcity appears to exert a somewhat stronger effect, increasing the risk of conflict to six percent for areas with very high levels of scarcity. For instance, in Nigeria, when herders and some few cases farmers failed to meet their needs in the Northern part of the country, they mostly migrate southward of the country to a greener pasture where there is more water and pasture (Obioha, 2005). Hence, with this pattern of movement existing or occurring, there will be pressure over scarce resources which if not managed well will increase the risk of conflicts and disputes between the indigenous and migrants.

\section{Water and Conflict through the Prism of Competing Agricultural User-groups in Nigeria}

Nigeria is endowed with diverse soil types and varied agro-ecological regions that offers great opportunities for the production of crops and rearing of livestock (Stojanov et al., 2014; Ide, 2015). The Nigeria's regional differentiations comes with a price; for example, more recently, the country agro-production tradition was expose to certain risks which are largely associated with the increasing climatic variability and ecological pressure posed by sharp conflicting competing users. Nigeria's agricultural productivities were largely at subsistence scale due to the actor's high reliance on traditional tools and methods. Both nomadic pastoralists and arable farmers are believed to be operating under high uncertainties and climatic perturbations in Nigeria (FAO, 1993; Tir and Diehl, 1998; Onuoha, 2008). That is why the search for water, forage and land by herders is identified by many studies as one of the fundamental catalysts of contemporary farmers-herders conflict in Nigeria (Azuwike and Enwerem, 2010; Ide, 2015; Amobi and Onyisi, 2015). 
Though water is directly linked with food production, however, some studies argued that most water-allied disputes are economic in nature; therefore, economic approach is anticipated to be more efficient in finding lasting solutions (Homer-Dixon, 1994; FAO, 2003; Ofuoku and Isife, 2009; Coetzee, 2012). It is estimated that 2020-2025, an estimated 80 percent of the additional food supplies required to feed the world will depend on irrigation (World bank, 2011).According to Shaw and Welburn (2014), there are about 120 million pastoral herdsmen globally, and more than 50 million were believed to residing in the subSaharan Africa's countries. Nigeria's livestock production sub-sector account for about 25 percent of the central and Western Africa entire livestock holding (World Bank, 2011).

With the invariable substantial cross-border movement of herdsmen into Nigeria from Niger, Mali and Chad, it is estimated that Nigeria alone has accounted for more than 50 percent of the beef consumption in whole of ECOWAS region (WRI, 2000; Ide, 2015).In most of the issues of water-allied conflicts and disputes, this study believed that the pastoralists are more disadvantaged because they need to persistently be on the move to find water and pastures for their animals. However, sedentary farmers in their desire to expand their farms to grow more food and increase their income, and have encroached on grazing lands, stock routes and blocked access to water points that were traditionally for the herders' livelihoods. Consequently, these farmers usually emphasize their rights of access to those resources whereas the pastoralists drive their animals into croplands people's farms to either consume or destroy crops.

In the quest to substantiate the axiom of water war, this study randomly interviewed people to ascertain whether they have witnessed any form of disagreement, conflict and dispute associated with water resources in their respective regions of resident. Below are some direct random excerpts from the interview:

"Yes, I have witnessed a lot" Anonymous pastoralist, 36years.

"Yes, even though I was never involved" Anonymous trader, 32years.

"Yes, but that was then" Anonymous businessman, 51 years.

"For access, its yes but beside that, I cannot think of any" Anonymous Civil servant, 39years.

"Children do fight while trying to collect water, and sometimes even their parents do get involve especially the ladies" Anonymous teacher, 54years.

"Mostly no within the major towns and cities, however, it is still common to fight over water resources in the rural areas" Anonymous traditional ruler, 67years.

The excerpt from the interview confirmed that significant amount of the or majority of the response acknowledged to have been a living witness of some forms of disagreement, conflict or dispute associated with water in their respective regions. Moreover, in an effort to determine the level of severity of the dispute and conflicts associated with water resources. Therefore, the following are some randomly selected excerpts from the interview conducted in ascertaining whether these conflicts and disputes have resulted to loss of life or property or both:

"Yes, they mostly resulted to loss of lives and properties..." Anonymous pastoralist, $59 y e a r s$.

"There are number of such conflicts that lives were loss and properties were destroyed" Anonymous trader, 61years.

"Take a look at what is happening lately in the middle belt region (of Nigeria) especially with Kaduna and Benue states are great examples" Anonymous businessman, 50years. 
"In most cases, when these conflicts happened, lives are lost and properties worth millions of naira were lost too" Anonymous Civil servant, 38years.

"Yes, even though most of localized conflicts here are mere exchange of words and verbal confrontations, whereas in cases where a migrant is involved, conflict often escalates to become full blown war due to fear of marginalization..." Anonymous lecturer, 62years.

"We only witness a few of them here, but from the experiences we had, we try as soon as possible to avert any loss of live or destruction of properties in case any conflict no matter the sources" Anonymous traditional ruler, 53years.

The excerpt from the interview further confirmed that most cases whenever waterallied conflicts and disputes ensue, regrettably, grave loss of lives as well as destruction of properties come about.

\section{Progresses so far}

Throughout the $20^{\text {th }}$ century, the axiom of water wars has been considered as a mere preposition rather than fact despite the availability of considerable number of literatures. For example, the role of water as a cause of conflict and disputes was believed to be highly controversial by many studies (Kartin, 2001; Gleditsch et al. 2002; Shiklomanov and John, 2003; Yoffeet al., 2004; Gleick, 2006; Kooy et al., 2015; von Lossow, 2016; Diep et al., 2017; Schillinger et al., 2020). However, these studies mostly acknowledged that water resources have been playing some bits in these conflicts and disputes, and many acts as a catalyst to some external factors. Another famous example is the study by Wolf (1997) that investigated the key cause of about 412 international crises for the period of 1918 to 1994; this study finds only seven cases which were directly related to access to freshwater, yet, in all the three conflicts no single shot were fired. The present study challenged Wolf (2007) conclusion of considering war as a stated where shot was fired neglecting the loss of lives no matter the magnitudes. Yet, Wolf (2007) affirmed the contemporary believe that access to freshwater has been an important cause of past wars.

This study like many other studies acknowledged the fact which argue that conflicts and disputes over water which happens in the past does not necessarily serve to predict the future, however, the study also believed that these literatures can be used to depict the existing state of affairs. Moreover, the recent turn of events of the $21^{\text {st }}$ century as depicted in many studies only focuses on prospective endeavours in terms of possible flashpoints for armed conflict and disputes in the various international river basins over water resources, however, these experts mostly overlook localize disputes and that sometimes results to huge loss of lives in addition to destruction of properties. This study is in sequence with the HomerDixon (1998) which argues on the basis of real-politik that wars over river water between upstream and downstream neighbours are likely only under a narrow set of circumstances.

Several studies have proved that over the past hundred or more years, armed conflicts and disputes over water-allied issues that resulted to at least one death are significantly and positively related to variables such as the weather condition or a regime (unconsolidated or autocratic), and also negatively related to such variables as years at peace and the level of economic development involved, as well as in some cases to whether they (at country level) have an alliance to each other (Toset et al., 2000; Furlong and Gleditsch, 2003; and Gleditsch, et al., 2004). This confirms the narrations that freshwater scarcity in its various forms has a strong influence on conflicts and disputes between farmers and pastoralists especially in developing economies like Nigeria, Somalia, Chad, and India. This finding is substantiated by 
Gardner (2010) and the Stockholm International Water Institute, (SIWI, 2008) who reported that water scarcity is growing in urgency in many regions as population growth, climate change, pollution, lack of investment, and management failures restrict the amount of water available relative to demand.

There are more than 1.4 billion people living around the world where water supply cannot meet their domestic, agricultural and industrial needs besides been less industrialized economies (UNEP, 2000; FAO, 2003). For example, about 3,500 square kilometres of Nigerian land is turning into desert forcing the region inhabitants (both farmers and herdsmen) to abandon their lands because their source of livelihood is destroyed (FAO, 2003; Campbell et al., 2007; Ludi, 2009; NASA, 2016). That is why this study affirmed the finding of Raleigh and Urdal (2009) that reported freshwater scarcity to be exerting a somewhat stronger negative effect which increases the risk of conflicts and disputes in areas with very high levels of scarcity and stress.

This study discovered many studies that supported this assertion with scientifically proven results; for instance, some studies conducted by Brown (2005) and Montenegro (2012) reported about of Sudan 18-months program by the United Nations Environment Program (UNEP) which concluded that the conflict in Darfur had its roots in water shortages, as a result of disappearing pasture and evaporating water holes. Another example is the shrinking of Lake Chad general area and the population that depends on it for their livelihood have found that it is indeed a worrisome trend (Onuoha, 2008; Vashney and Hasssan, 2019).

Many studies acknowledged the increasingly rising incidence of conflict between and among fishermen, pastoralists, and some instances including state security agents (Yoffe et al., 2004; Ludi, 2009). These conflicts tend to have higher tendencies of causing momentous conflicts and disputes that often degenerate into large scale intra-ethnic, intra-state, inter-state as well as ethno-religious conflicts and disputes. These conflicts and disputes mostly worsen considerably as water scarcities interact with or exacerbate other conflict-related social variables (Miguel et al., 2004; Ofuoku and Isife, 2009; Coetzee, 2012; Aderinoye-Abdulwahab and Adefalu, 2012; Amobi and Onyisi, 2015). For example, there are confirmed reports that serious conflicts and disputes happening around Niger, Mali and Burkina Faso have forced many sedentary groups to relocate due to water scarcity (Ibrahim, 2011; Ofem and Bassey, 2014).

Water as a finite resource in the facade of the earth is significantly affected by the global population boom. In view of the existing mechanisms, it is easy to affirm the preposition that the available global water is shrinking. In Nigeria for instance, both farmers and pastoralists from the Northern region are finding it more difficult to sustain their vocations, therefore, resorted to moving to the Southern part of the country as a result (Crossette, 1995; Azuwike and Enwerem, 2010; ACCES, 2010; Ofem and Bassey, 2014; Gleick, 2019). This increases mobility by the nomadic herders which in turn pitches them against the sedentary farmers. The Southern region of Nigeria lately receives huge influx of environmental migrants not only from the Northern extraction but to as far as Mali, Sudan and Chad (Azuwike and Enwerem, 2010; Ofem and Bassey, 2014). Consequently, this scenario pushes the two competing resource user-group (indigenous arable farmers and non-indigenous nomadic pastoralists) into tenuous system cohabitation in the Southern part of Nigeria.

Moreover, the Southern region of Nigeria is also not totally immune to its own form of expose to adverse effect of climatic variability, issues of land use land cover changes, 
pollution, soil erosion, etc.(Aderinoye-Abdulwahab and Adefalu, 2012; Ofem and Bassey, 2014; Amobi and Onyisi, 2015). That is why many studies believed that the intensification of long-range grazing southward by the nomad pastoralists succinctly explains the recurrent communal friction and conflict with the host communities in the Southern Nigeria (Abdul Wahab and Adefalu, 2012; Amobi and Onyisi, 2015). Issues such as sources of water, management of the sources as well as the duration of rainfall were found to be the most potent predictors of causes of conflict between the farmers and herders (Thomas, 2002; Azuwike and Enwerem, 2010; Ofem and Bassey, 2014).In view of the loads of literatures reviewed, this study established that it is evident that conflict and dispute for whatever reasons would consequently undermines social order, threatened peace, human security, national stability and beyond. Therefore, the present study held the view that water-allied issues shared with persistent conflict and dispute would certainly destabilizes the communities and nation at large and would consequently impedes food production, and thus threatened food security.

\section{Conclusion}

Water is a catalyst for both war and peace. Water-allied issues are believed to the most pressing concerns of both existing and next millennium. With the conception that water war is eminent in our contemporary societies, the present study critically investigates the notion as either been a legend or phenomenon? In conclusion, this study assumed from the foregoing literatures associated to water-allied conflicts and disputes induced by issues are strongly believed to be interminable. However, the recent global competition in pursuits for various developmental upgrades have proved that the notion of water war is neither a legend nor conspiracy but a modern phenomenon that is already happening. This is further supported by the fact that relationship between water-allied issues and conflict is multifaceted and heterogeneous in nature; because it is associated with many factors such as occupational characteristics, climate change, migration, ethnic cleavages, religious affiliation, levels of income as well as level of education.

The present study adopted the theory of the tragedy of the commons and conflict in order to conceptualize the issue of water war in accordance with theory of relative deprivation by examining the nexus of water and arable-pastoralist activities in Nigeria. Viewed from the relative deprivation theoretical prism, with focus on developing economies of Africa (explicitly choosing Nigeria as a case study), and the study have recognized certain indirect factors. These factors include rapid climatic changes, host communities fear of marginalization, environmental variability, increasing demand for food production, rapid population increase and pressure as well as other contingency factors that are believed to be contributing to water war. Moreover, other extraneous factors such as religious intolerance, perceived ethnic dominations, ethno-religious phobia, misinformation, and poverty can never be left out too.

This study held the view that occupational politics, demographic explosion as well as ecological pressure resulting from water-allied concerns usually aggravates the livelihood constrictions and struggles among individuals and groups, and consequently led to grave loss of lives and destruction of properties. Hence, water war is a complex setting of affairs that have heterogeneous linkages to diverse assorted physical, economic, social, political issues as well as developmental initiatives; that is why there are serious potency for disputes or conflicts in areas with water stress and scarcity around the world; for example, sub-Saharan African countries like Nigeria, Sudan, Somalia, Libya, and Ethiopia, as well as some Asian countries such as China, India, Pakistan, and Bangladesh.

This study believed that the magnitude of water war phenomenon varies significantly between the developed and the developing economies as well as the region economic power; 
the economically stable regions having lesser chances of water war whereas the economically unstable regions having higher chances of the notion. Therefore, this study made the following suggestions:

[i] There is need for both farmers and nomads 'pastoralists to respect and live each other's rights and obligation; such as cultural, ethno-religious as well as economic proceedings in their interactions. This can be strengthened through adoption of effective land use land cover in addition to effective land tenure agreements. Moreover, farmers should avoid encroaching on the stock routes mapped out for the pastoralists, on the other hand the pastoralists too must also avoid indiscriminate destruction of farmland and crops during their quest for greener pasture.

[ii] Conflicts between the two parties must be constructively resolved by the governments at all level to ensure peaceful coexistence and inter dependence.

[iii] States on the fringes of arid and semi-arid region like the Sahara desert should intensify afforestation programs in order to mitigate the impact of the desert encroachment.

[iv] Since agriculture now accounts for roughly about 70 percent of water withdrawals in the world, controlling waste in this sector is a useful starting point with currently less than half the total global water resources are diverted from reservoirs for irrigation to produce food for the earth ever growing population.

[v] There is need for devising an effective mediation that can help defuse potential waterallied conflicts and disputes, since the global capacity for such mediation has been enhanced lately through the adoption of development of new technical and financial instruments, dispute resolution institutions as well as internationally recognized water treaties.

[vi] Lastly, there is need for careful sensitization programs especially in anticipated water threatened regions of the world in order to mitigate and curtail any prospective water-allied dispute and conflict.

\section{References}

1. Abdeen, M. (2010). Africa: The Driest Continent. Available from: https://www.novapublishers.com/catalog/product_info.php?products_id=16606.

2. Abbass, I. M. (2012). No Retreat, No Surrender. Conflict for Survival between Fulani Pastoralists and Farmers in Northern Nigeria. European Scientific Journal, vol. 8, No. 1, pp 337-352.

3. Abbass, I. M. (2011). No Retreat, No Surrender: Conflict for Survival between Fulani Pastoralist and Farmers in Northern Nigeria. European Scientific Journal, 8(1), 153-166.

4. Abu-Lohom, N. M., Konishi, Y., Mumssen, Y., Zabara, B. and Moore, S. M. (2018). Water supply in a war zone: A preliminary analysis of two urban water tanker supply systems in the Republic of Yemen. Washington, DC: The World Bank.

5. ACCES. (2010). Climate Change and Security in Africa: Vulnerability Report. The Africa, Climate Change, Environment and Security (ACCES) Dialogue Forum, Event Report 11, UN Conference Centre, Addis Ababa, Ethiopia.

6. Adano, W. R., Dietz, T., Witsenburg, K. and Zaal, F. (2012). Climate Change, Violent Conflict and Local Institutions in Kenya's Drylands. Journal of Peace Research, 49, 65-80.

7. Aderinoye-Abdulwahab, S. A. and Adefalu, L. L. (2012, February 7-10). Pastoral Communities in Nigeria: Another Case of Marginalisation. 56th Australian Agricultural and Resource Economics Society (AARES) Annual Conference, Fremantle, Western Australia.

8. Amobi, D. and Onyisi, T. (2015). Governance and Climate Change in Nigeria: A Public Policy Perspective. Journal of Policy and Development Studies, 9(2), 199-209.

9. Alcamo, J. and Thomas H. (2002). Critical Regions: A Model-Based Estimation of World Water Resources Sensitive to Global Changes. Aquatic Sciences 64(4): 352-62.

10. Ashton, P. (2000). Southern African Water Conflicts: Are they Inevitable or Preventable? The African Dialogue Lecture Series Pretoria University. 1-5. Available from: http://www.waterwiki.net/images/7/76/Ashton_Southern_Africain_Water_Conflicts_2000.pdf.

11. Azuwike O. D. and Enwerem, E. (2010). Nigeria's Changing Environment and Pastoral Nomadism: Redistribution of Pains and Gains. Owerri: Imo State University 
12. Baechler, G. (1999). Violence through Environmental Discrimination: Causes, Rwanda Arena, and Conflict Model. Dordrecht: Kluwer Press.

13. Baechler, G. (1999). Environmental Degradation and Violent Conflicts: Hypothesis, Re- search Agendas and Theory-building. In M. Suliman (Ed.), Ecology, Politics and Violent Conflicts. New York: Zed Books.

14. Black, R., Kniveton, D., Skeldon, R., Coppard, D., Murata, A. and Schmidt-Verkerk, K. (2008). Demographics and Climate Change: Future Trends and their Policy Implications for Migration, Working Paper T-27. London: DFID.

15. Buseth, J. T. (2009). Conflicting Livelihoods and Resources in the Time of Global Warming: The Political Ecology of Farmer-Herder Conflict in Mopti, Mali. Noragic: Department of International Environment Studies, Norway.

16. Brown, L. (2005). Planet under Stress. 37-51 in John S. Dryzek and David Schlosberg, eds., Debating the Earth. New York: Oxford University Press.

17. Crossette, B. (1995). Severe Water Crisis Ahead for Poorest Nations in Next Two Decades, New York Times, August 10: A13.

18. Coetzee, W. S. (2012). The role of Environment in Conflict: Complex Realities in Post-Civil War Nigeria. Stellenbosch: Stellenbosch University.

19. Davis, J. A. (1959). A formal interpretation of the theory of relative deprivation. Sociometry, 22, 280 296.

20. Dowdeswell, T. L. and Hania, P. (2014). Regulating water and war in Iraq: A dangerous dark side of new governance. Indiana Journal of Global Legal Studies, 21(2), 453-482.

21. Diep, L., Hayward, T., Walnycki, A., Husseiki, M. and Karlsson, L. (2017). Water, crises and conflict in MENA: How can water service providers improve their resilience? (IIED Working Paper). London, England: International Institute for Environment.

22. Downing, T. E. and Patwardhan, A. (2003). Vulnerability Assessment for Climate Adaptation. UNDP Adaptation Policy Framework Technical Paper 3. New York: UNDP.

23. Evans, A. (2010). Resource Scarcity, Climate Change and the Risk of Violent Conflict. World Development Report 2011 Background Paper.

24. Falkenmark, M. (1989). The Massive Water Scarcity Now Threatens Africa. Ambio 18(4): 268-75.

25. Food and Agricultural Organization. (1993). The State of Food and Agriculture 1993. Rome: FAO.

26. Food and Agricultural Organization. (2003). The State of Food Insecurity in the World. Rome: FAO.

27. Food and Agricultural Organization. (2003). FAO Stat. Accessed October 4, 2020. $<$ http://faostat.fao.org/faostat/collections?subset=agriculture $>$.

28. Gartzke, E. (2011, November 15). Blame it on the weather: Seasonality in interstate conflict. Working Paper. San Diego: University of California.

29. Gray, C. and Bilsborrow, R. (2013). Environmental Influences on Human Migration in Rural Ecuador, Demography, 1-25.

30. Gleick, P. H. (1993). Water and conflict: Fresh water resources and international security. International Security, 18(1), 79-112.

31. Gleick, P. H. (2006). Water and terrorism. Water Policy, 8(6), 481-503.

32. Gleick, P. H. (2019). Water as a weapon and casualty of conflict: Freshwater and international humanitarian law. Water Resources Management, 33(5), 1737-1751.

33. Groninger, J. W., Ruffner, C. M. and Christenson, L. (2015). Water resources development considerations for civilian and military institutions working in highly insecure areas: Lessons from Afghanistan. International Journal of Water Resources Development, 31(4), 486-498.

34. Gleditsch, N., Petter, P., Wallensteen, M., Erikson, M. S. and Håvard, S. (2002). Armed Conflict 1946-2001: A New Dataset, Journal of Peace Research 39(5): 515-39.

35. Gleick, P. H., ed. (1993). Water in Crisis: Guide to the Worlds Fresh Water Resources. New York: Oxford University Press.

36. Gowan, R. (2017). Bordering on crisis: Europe, Africa, and a new approach to crisis management Available from: https://www.ecfr.eu/publications/ summary/bordering_on_crisis_europe_africa_and_a_new_approach_to_crisis_manageme 7281 .

37. Hauge, W. and Tanja, E. (1998). Beyond Environmental Scarcity: Causal Pathways to Conflict. Journal of Peace Research, 35(3): 299-317.

38. Homer-Dixon, T. and J. Blitt, Eds. (1998). Eco violence, Links among Environment, Population, and Security. Oxford: Rowman \& Littlefield Publishers.

39. Homer-Dixon, T. (1994). Environmental Scarcities and Violent Conflict: Evidence from Cases. International Security, Vol. 19, No. I (Summer 1994), 5-40.

40. Ide, T. (2015). Why do conflicts over scarce renewable resources turn violent? A Qualitative Comparative Analysis. Global Environmental Change, 33, 61-70.

41. Kartin, A. (2001). Water scarcity problems in Israel. Geo-Journal, 53, 273-282.

42. Koubi, V., Spilker, G., Bo" hmelt, T. and Bernauer, T. (2014). Do Natural Resources matter for Interstate or Intrastate Armed Conflict? Journal of Peace Research, 51, 227-243. 
43. Kratli, S. (2008). Cattle breeding, complexity and mobility in a structurally unpredictable environment: the WoDaaBe herders of Niger. Nomadic Peoples, 12(1), 11-41.

44. Kooy, M., Wild, L. and Mason, N. (2015). Doing things differently: Can water supply, sanitation, and hygiene services support peace- and state-building processes? Development Policy Review, 33(4), 433-456.

45. Konczacki, Z. (1978). The Economics of Pastoralism: A Case Study of Sub-Saharan Africa. London: Frank Cass.

46. Ludi, E. (2009). Climate Change, Water and Food Security. Available at http://www.odi.org.uk.

47. Mearns, R. and Norton, A. (2010). Social Dimensions of Climate Change. Washington D.C: The World Bank, 47-74.

48. Myers, N. (2002). Environmental refugees: a growing phenomenon of the 21st century. Philosophical Transactions of the Royal Society of London Series B, Biological Sciences, 357 (1420), 609-613.

49. Miguel, E., Satyanath, S. and Sergenti, E. (2004). Economic Shocks and Civil Conflict: An Instrumental Variables Approach, Journal of Political Economy, 112(4), 725-753.

50. Murray, S. (2007). Water Wars in Arid North Nigeria. http://news.bbc.co.uk/2/hi/africa/6569057.stm

51. NASA. (2016). Climate Trends Continue to Break Records. Available from: https://www.nasa.gov/feature/goddard/2016/climate-trendscontinue-to 'break-records.

52. Norland, E. (2016). The future of food demand: China, Africa, and India Future of Food: Growing Global Appetites.

53. Ngigi, S. N. (2009). Climate Change Adaptation Strategies: Water Resources Management Options for Smallholder Farming Systems in Sub-Saharan Africa. New York: The MDG Centre for East and Southern Africa of the Earth Institute at Columbia University.

54. Nyong, A. and Fiki, C. (2005). Drought-Related Conflicts, Management and Resolution in the West African Sahel: Human Security and Climate Change. An International Workshop Holmen Fjord Hotel, Asker, near Oslo, 21-23 June.

55. Obioha, E.E. (2005). Climate Change, Population Drift and Violent Conflict over Land Resources in North Eastern Nigeria. A paper presented at the International Workshop on Human Security and Climate Change, Oslo, June 21-23.

56. Oberschall, A. (1978). Theories of Social Conflict. Annual Review of Sociology, 4, 291- 315.

57. Ofem, O. O. and Bassey, I. (2014). Livelihood and Conflict Dimension among Crop Farmers and Fulani Herdsmen in Yakurr Region of Cross River State. Mediterranean Journal of Social Sciences, $5(8), 512-519$.

58. Ofuoku, A. U. and Isife, B. I. (2009). Causes, Effects and Resolution of Farmers-Nomadic Cattle Herders Conflict in Delta State, Nigeria. International Journal of Sociology and Anthropology, 1(2). 47-54.

59. Onuoha, F. C. (2008). Environmental Degradation, Livelihoods and Conflicts: A focus on the Implications of the Diminishing Water Resources of Lake Chad for North-Eastern Nigeria. African Journal on Conflict Resolution, 8(2), 35-62.

60. Oyetade, L. (2007). Farmers in Northern Nigeria Suffer Effects of Desertification.

61. http://www.africanagricultureblog.com/2007/03/farmers-in-northern-nigeria-suffer.html

62. Pallett, J. (1997). Sharing Water in Southern Africa. Desert Research Foundation of Namibia. Windhoek: Namibia.

63. Percival, V. and Homer-Dixon, T. (1998). Environmental Scarcity and Violent Conflict: The Case of South Africa. Journal of Peace Research, 35, 279-298.

64. Raleigh, C. and Urdal, H. (2009). Climate Change, Demography, Environmental Degradation, and Armed Conflict. Environmental Change and Security Program (ECSP) Report, Issue 13. Responsibilities http://www.unwater.org /downloads/unw_transboundary.pdf

65. Renzetti, S. (2002). The Economics of Water Demands. Boston: Kluwer.

66. Schillinger, J., Özerol, G., Sermin Güven-Griemert, S. and Heldeweg, M. (2020). Water in war: Understanding the impacts of armed conflict on water resources and their management. WIREs Water, 7: e1480.

67. Smith, R. (1999). Africa's potential water wars. Available from: http://www.news.bbc.co.uk/2/hi/africa/454926.stm. [Last accessed on 2017 Apr 25]

68. Stojanov, R., Kelman, I., Shen, S., Duží, B., Upadhyay, H., Vikhrov, D., Lingaraj, G.J. and Mishra, A. (2014). Contextualising Typologies of Environmentally Induced Population Movement. Disaster Prevention and Management: An International Journal, 23(5), 508- 523.

69. Tir, J. and Diehl, P. (1998). Demographic pressure and interstate conflict: linking population growth and density to militarized disputes and wars, 1930-89. Journal of Peace Research, 35(3), 319-339.

70. Treszkai, A. (2016). Security Risks in Africa: Water Conflicts Defence Review Volume 144. Special Issue 2016/1. p. 146-158. Available from: https://www.hvktkh.hm.gov. hu/ kiadvanyok /dokumentumok/dr/2016_1.pdf. 
71. Turton, A. R. (2000). Water wars in southern Africa: Challenging conventional wisdom. Proceedings of the African Dialogue Lectures Hydropolitical Hotspots in Southern Africa: Will There be a Water War? University of Pretoria.

72. United Nations-Water (2008). Transboundary Waters: Sharing Benefits, Sharing Responsibilities http://www.unwater.org/downloads/unw_transboundary.pdf

73. United Nations. (2017). International Migration Report. Available from: http://www.un.org/en/development/desa/population/migration/publications/migrationreport/docs/Mi grationReport2017_Highlights.pdf.

74. UNEP (United Nations Environment Programme). (2000). Global Environment Outlook (GEO) 2000. <www.grida.no/geo2000/english/0236.htm>.

75. Varshney, D. and Hassan, Y. (2019). Lake Chad in Adversity: Chronicles of Past, Present and Future. Journal of Gujarat Research Society, 21(15), 465-476.

76. vonLossow, T. (2016). The rebirth of water as a weapon: IS in Syria and Iraq. The International Spectator, 51(3), 82-99.

77. Wenzlau, S. (2010). As Rivers Run Dry: A Study of Global Freshwater Scarcity and its Implications for Socioeconomic Development."http://digitalcollections.sit.edu / isp_collection / 956

78. Wolt, K. (2011). Climate Change, Environmental Scarcity, and Violent Conflict: Examining Primers and Analyses. Washington: The Evergreen State College.

79. World Bank. (2011). World development report 2011: Conflict, security, and development. Washington, DC: World Bank.

80. WHO (World Health Organization). (2000). Global Water Supply and Sanitation Assessment 2000 Report <www.who.int/docstore/ water sanitation_health / Globassessment/GlobalTOC.ht

81. Wolf, A. T. (1997). Water Wars and Water Reality: Conflict and Cooperation Along International Waterways. 251-65 in S.C. Lonergan, ed. Environmental Change, Adaption, and Security. Boston: Kluwer.

82. World Meteorological Organization. (1997). Comprehensive Assessment of the Freshwater Resources of the World. New York: United Nations.

83. World Resources Institute. (2000). World Resources, 2000-2001: People and Ecosystems. Washington, D.C.

84. Wolf, A. T. (2007). Shared waters: Conflict and cooperation. Annual Review of Environment and Resources, 32, 241-269.

85. Yoffe, S. et al. (2004). Geography of International Water Conflict and Cooperation: Data Sets and Aokucatuibs: Water Resources Research, 40(5): W05S04. 